\title{
Improving the methods for determining the promising boundaries of iron ore open pits
}

\author{
Serhii Lutsenko ${ }^{1}$, Yulian Hryhoriev ${ }^{1}$, Volodymyr Peregudov ${ }^{2}$, Aidar Kuttybayev ${ }^{3}$, and Asel Shampykova ${ }^{3}$ \\ ${ }^{1}$ Kryvyi Rih National University, 11 Vitalii Matusevych Str., Kryvyi Rih, 50027, Ukraine \\ ${ }^{2} \mathrm{SE}$ «SDI «Krivbassproekt», 40 Poshtovyi Ave., Kriviy Rih, 50000, Ukraine \\ ${ }^{3}$ Satbayev University, 22a Satpaeva str, Almaty, 050013, The Republic of Kazakhstan
}

\begin{abstract}
The article considers the determination of the final contours of the open pits. One of the problems of development of iron ore deposits at the present stage of development of opencast mining is described, which consists in the fact that in most open pits their working contours on the surface have reached final position. In these conditions, it is necessary to reevaluate the capabilities of the raw material base for further operation of mining enterprises. The analysis of scientific achievements in the decision of the final definition of the open pits ' contours is executed. The well-known principle of determining the boundaries of opencast mining, the principle of which is to determine the boundaries based on a comparison of the allowable cost of ore production with the expected for the designed open pit. On the example of the open pits, which reflect the characteristic features of the development of steep-dipping deposits of Ukraine, the influence of current overburden ratio of the existing open pits on the economic overburden ratio, which serves as the main criterion in determining the boundaries of opencast mining for the designed open pits. A method for determining the boundaries of the open pits has been developed, which provides for the use of the economic overburden ratio of opening as a value not constant but variable over time, and one that depends on the change of current coefficients of opening in open pits-competitors. As a result, the theory in the field of determining the final contours of the open pits is improved. The new method differs from the known ones by taking into account the change in the economic overburden ratio over time, as well as determining the impact of technological indicators of open pits competitors on the final depth of the designed open pit.
\end{abstract}

\section{Introduction}

One of the main parameters in the design of opencast mining is the boundaries of the open pit.

At present, the upper horizons of most iron ore open pits are approaching their design boundaries. Therefore, the work of open pits will be characterized by the achievement of the highest operating overburden ratios.

This will lead to the fact that the cost of ore and in general the cost of production of concentrate will reach the acceptable values. Based on this, the value of the operating overburden ratio, which determines the final boundaries of the open pits, can be reduced by choosing the direction of development of mining operations and determining the rational contours of the open pits on the surface. Reducing the operating factor will expand the final boundaries of the open pits, thereby increasing the ore reserves in the contours of the open pits and the industrial potential of mining and processing plants [1].

It should be noted that timely determination of the final contours of the open pits allows you to plan the need for land for surface buildings and technological structures that ensure the normal operation of mining and processing plants for a long time [2]. At the same time, the social factor is also important.

The need to determine the promising final boundaries of the open pit is due to the fact that after the upper horizons to the final contour of the open pit will work in the mode of annual reduction (disposal) of production capacity, and to prepare the overlap of such disposal it will take 5-7 years at any method of development. It will increase the depth of development of the deposit, and most of the upper horizons of the working area will be repaid, which will require attracting much more investment in the development of reserves in the approved by the designed contour of the open pit.

With the definition of promising final contours of the open pit there will be a change in the volume of overburden, ore and its quality, at which it is necessary to establish its production capacity and the period of the plant operation.

\section{Object and methods of research}

Significant achievements [3-16] in the theory of designing the boundaries of opencast mining belong to M.I. Goberman, W.W. Rzhevsky, V.S. Khokhryakov, O.I. Arsentiev, M.S. Chetverik, V.G. Blizniukov. Of course, the determination of the boundaries of open pit mining should be carried out taking into account the conditions of stability of the massif of boundary rocks, which are performed by modern remote methods $[17,18]$. When determining the boundaries of the open pits according to known calculation principles, the economic 
calculating ratio is calculated according to technical and economic indicators, which are achieved at the time of design and its value is constant [19-21].

In study [22], a method was proposed to determine the economic overburden ratio, which allows avoiding of the influence of unnatural and non-technological factors on the price of concentrate. The developed method allows to bring prices at the cost of one percent of iron in 1 ton of concentrate and to avoid the influence of subjective factors while the determining the boundaries of opencast mining.

Analysis of the work of mining and processing plants showed that their economic indicators and overburden ratios change over time [23]. It was found that the existing methods of determining the boundaries of the open pits do not take into account the possibility of changing the economic overburden ratio due to the inconsistency of technical and economic indicators, in particular, the cost of ore production in a competitive environment [24].

The enterprises develop minerals in an open way there is a constant change in the volume of overburden per ton of the extracted ore, which entails significant changes in the cost of marketable products $[25,26]$. Ignoring the change in the economic overburden ratio over time can lead not only to exceed, but also to the reduction of economic sense depth of the designed and existing open pits.

Therefore, the idea was put forward to take into account the dynamics of the external competitive environment of the mining company and determine the boundaries of opencast mining, based on the fact that the cost of ore mining in the designed open pit in every operation period should be no more than on other enterprises of the same industry, that conduct mining operations both open and underground methods.

Therefore, the goal was to prove that economic overburden ratio is not constant, but changes over time and will significantly depend on the final depth of the open pit.

\section{Results}

Many calculation principles for determining the boundaries of the open pits are based on the condition the allowable cost of ore mining $\left(c_{m}\right)$ should be more or equal to the cost of ore mining in the designed open pit:

$$
c_{m} \geq c_{a}, \mathrm{UAH} / \mathrm{t} .
$$

It should be noted that the allowable cost is the cost of ore of one of the basic mining companies-competitors with an open method of deposit development. Moreover, the allowable cost of ore is taken as it is at the time of designing a new open pit or reconstruction of an existing one.

The expected cost of ore for the designed open pit is calculated depending on the value of the overburden ratio $\left(n_{d}\right)$ by the formula:

$$
c_{a}=a+b \cdot n_{d}, \mathrm{UAH} / \mathrm{t},
$$

where $a$-the cost of ore production without the overburden cost, UAH $/ \mathrm{t} ; b-$ overburden cost, $\mathrm{UAH} / \mathrm{m}^{3}$; $n_{d}$ - overburden ration in the designed open pit, $\mathrm{m}^{3} / \mathrm{t}$.

After substituting the expected value of the cost of ore mining and transformation the inequality (1), formula (2) will take the following form:

$$
\frac{c_{a}-a}{b}=n_{d}, \mathrm{~m}^{3} / \mathrm{t}
$$

The left part of expression (3) determines the value of the economic overburden ratio $\left(n_{e}\right)$ and then, taking into account expressions (1,2 and 3), we obtain the inequality

$$
n_{\mathrm{e}} \geq n_{d}, \mathrm{~m}^{3} / \mathrm{t}
$$

Based on the above mentioned, the condition of competitiveness of the designed open pit can be formulated as follows: the overburden ratio in the designed open pit should not exceed the economic overburden ratio, which takes into account the economic performance of the existing (base) company.

It should be noted that in the regulations providing the work of mining companies with an open method of development [27], the calculated economic overburden ratio to determine the final depth of the open pit is taken as a constant value. However, the basic enterprisecompetitor continues its work, and its economic performance will change over time [28], in our case - the cost of ore. The reason for this is the change in the current overburden ratios upward or downward.

Consider the example of two conditional basic openpits-competitors possible changes in current overburden ratios (Fig. 1 and 2).

Conditional basic open pit-competitor №1 develops ore deposit, in which: the incidence angle is $80^{\circ}$; horizontal width $-350 \mathrm{~m}$; length $-2700 \mathrm{~m}$. Open pit parameters: angle of inclination of the working side $-16^{\circ}$; the angle of inclination of the designed side $-45^{\circ}$; the final depth of the open pit is $630 \mathrm{~m}$. It should be noted that in this open pit the surface boundaries have already approached the design position and further development of the open pit is carried out with the development of mining only in depth.

Conditional basic open pit-competitor № 2 (Fig. 2) develops an ore deposit in which: the incidence angle is $80^{\circ}$; horizontal width $-120 \mathrm{~m}$; length $-4500 \mathrm{~m}$. Parameters of this open pit: angle of inclination of the working side $-16^{\circ}$; the angle of inclination of the designed side $-45^{\circ}$; the final depth of the open pit is $345 \mathrm{~m}$.

In the conditional base open pit-competitor № 2 , in contrast to the considered conditional base open pitcompetitor № 1, the boundaries on the surface have not yet approached the design position and further development of the open pit is carried out with the mining works development, both in the horizontal direction, and in depth.

In the figures 1 and 2, the numbers $0,30,60,90,120$ indicate the steps of reduction of mining works in conventional base open pit-competitors every $30 \mathrm{~m}$. The position of the working side of the open pit at step "0" characterizes the current state of mining works in the open 
pit and serves as a starting point for further research of their development.

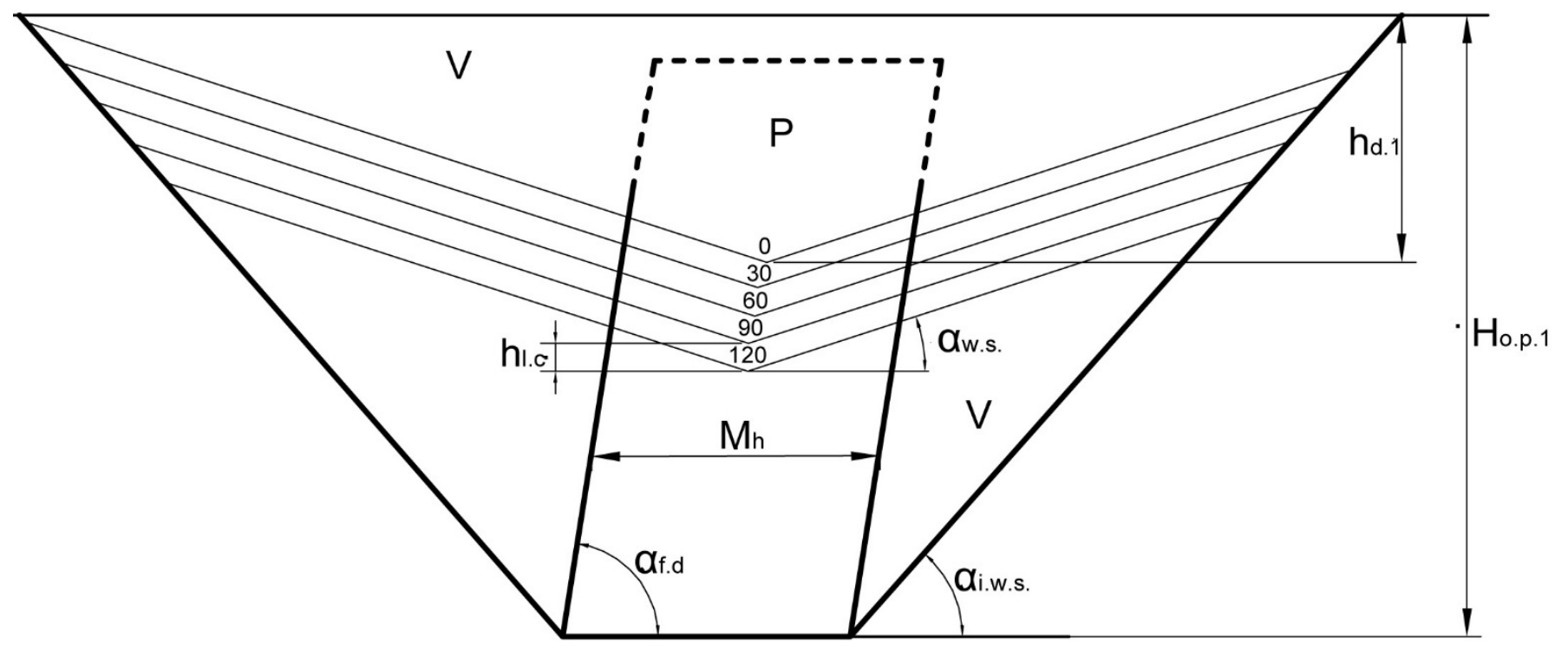

Fig. 1. Open pit-competitor № 1: V - overburden rocks; $\mathrm{P}$ - ore; $\mathrm{h}_{\mathrm{d} .1}$ - current depth of mining works; $\mathrm{h}_{1 . \mathrm{c} .}-$ step of reduction of mining works; $\alpha_{\text {w.s. }}-$ angle of inclination of the working side of the open pit; $\alpha_{\text {i.w.s }}-$ angle of inclination of the designed side of the

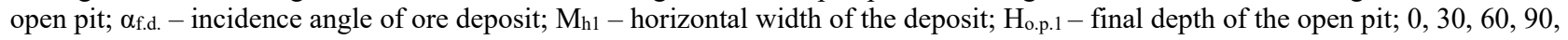
120 - step of reduction of mining works in the open pit.

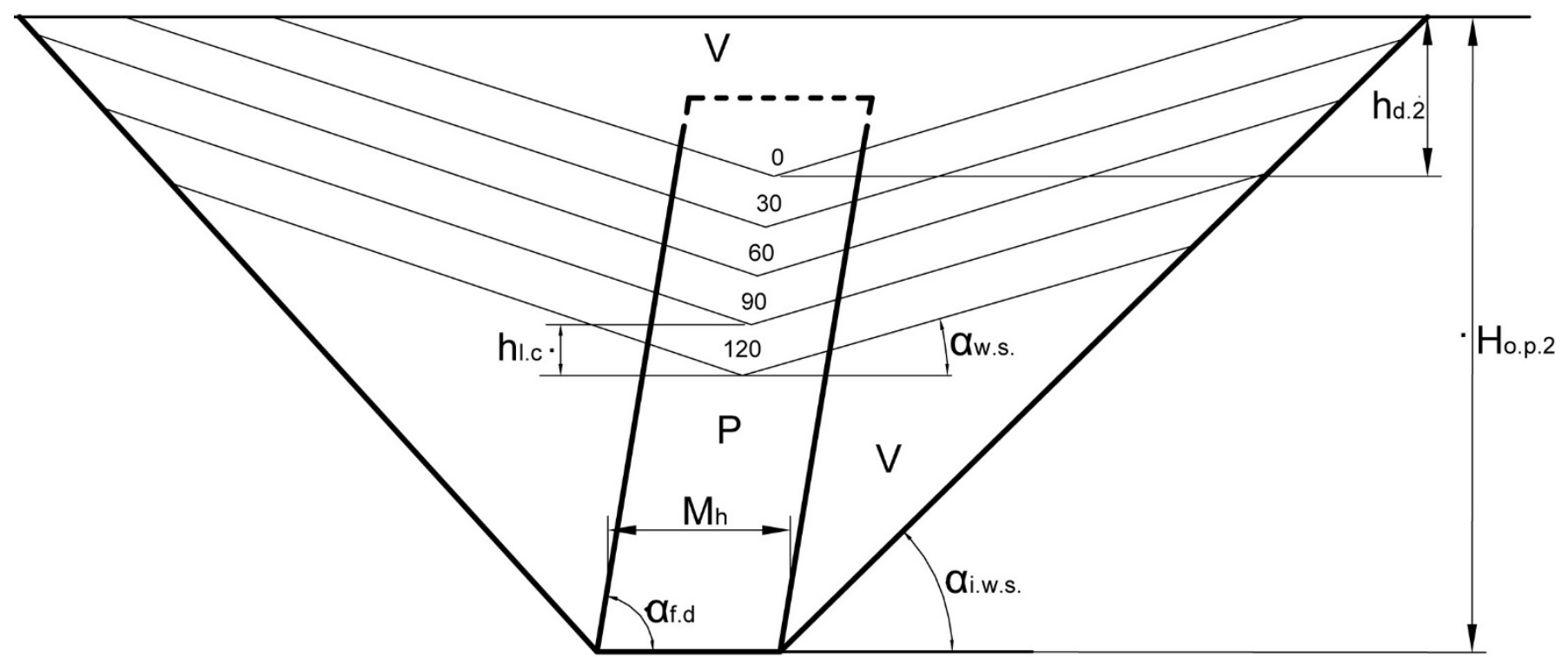

Fig. 2. Open pit-competitor № 2: $\mathrm{V}$ - overburden rocks; $\mathrm{P}$ - ore; $\mathrm{h}_{\mathrm{d} .2}$ - current depth of mining works; $\mathrm{M}_{\mathrm{h} 2}$ - horizontal width of the deposit; $H_{0 . p .2}$ - final depth of the open pit.

The positions of the working sides of conventional base open pits-competitors at the zero step are selected so that the ore bodies were cut to full horizontal width, and the value of the current coefficients was the same as the value of the calculated economic overburden ratio.

When designing a new open pit, it is necessary to determine the prospective depth of opencast mining first: it will determine the boundaries of the open pit on the surface and the possible productivity of the open pit for minerals. The condition for determining the prospective boundaries of the designed open pit is to obtain economic indicators of the designed open pit not worse than the economic indicators of the existing open pits. This condition is written by inequality (4).

To determine the final depth of the future conditional (designed) open pit, a typical section of the deposit is selected in which: the incidence angle is $80^{\circ}$; horizontal width $-230 \mathrm{~m}$; length $-3200 \mathrm{~m}$. All open pits exploit the reserves of the same type of mineral with the same quality, and the existing technology allows them to work with relatively equal costs for extraction of one ton of overburden and mining of one ton of ore.

As on the conditional base open pits-competitors №1 and №2, and for the conditional open pit that is designed, 
from the position of the working sides at the zero step we rebuild their further position at the steps of mining development every $30 \mathrm{~m}$ in depth. At each step we determine the volumes of ore and overburden with the definition of the current overburden ratio, the results of the calculations are entered in Table 2.

Table 1. Volumes of ore and overburden, as well as current overburden ratio according to research options.

\begin{tabular}{|c|c|c|c|c|c|c|c|c|c|}
\hline \multirow{2}{*}{$\begin{array}{l}\text { Deepening } \\
\text { of the open } \\
\text { pit, } m\end{array}$} & \multicolumn{3}{|c|}{ Conditional basic open pit № 1} & \multicolumn{3}{|c|}{ Conditional basic open pit № 2} & \multicolumn{3}{|c|}{ Conditional designed open pit } \\
\hline & Ore, $\mathbf{m}^{3}$ & $\begin{array}{c}\text { Overburden, } \\
\mathbf{m}^{3}\end{array}$ & $\begin{array}{l}\begin{array}{l}\text { Overburden } \\
\text { ratio, } \mathbf{m}^{3} / \mathbf{m}^{3}\end{array} \\
\end{array}$ & Ore, $\mathbf{m}^{3}$ & \begin{tabular}{|c} 
Overburden, \\
$\mathbf{m}^{3}$
\end{tabular} & $\begin{array}{l}\begin{array}{l}\text { Overburden } \\
\text { ratio, } \mathbf{m}^{3} / \mathbf{m}^{3}\end{array} \\
\end{array}$ & Ore, $\mathbf{m}^{3}$ & $\begin{array}{c}\text { Overburden, } \\
\mathbf{m}^{3}\end{array}$ & $\begin{array}{l}\text { Overburden } \\
\text { ratio, } \mathrm{m}^{3} / \mathrm{m}^{3}\end{array}$ \\
\hline 0 & 28080000 & 101250000 & 3,6 & 16425000 & 59400000 & 3,6 & 21920000 & 47680000 & 2,2 \\
\hline 30 & 28080000 & & 3,4 & 16425000 & & 4,9 & & & 3,1 \\
\hline 60 & 28080000 & & & 16425000 & & & 21920000 & & 4,0 \\
\hline 90 & 28080000 & & & 16425000 & & 5,6 & 21920000 & & 5,0 \\
\hline 120 & 28080000 & 78435000 & 2,8 & 16425000 & 90000000 & 5,5 & 21920000 & 126880000 & 5,8 \\
\hline
\end{tabular}

Table 2. Current overburden ratio on open pits of Kryvbas in 2010-2020 yy.

\begin{tabular}{|c|c|c|c|c|c|c|c|c|c|c|c|}
\hline \multirow{2}{*}{ Open pit } & \multicolumn{10}{|c|}{ Years of exploitation } \\
\cline { 2 - 14 } & $\mathbf{2 0 1 0}$ & $\mathbf{2 0 1 1}$ & $\mathbf{2 0 1 2}$ & $\mathbf{2 0 1 3}$ & $\mathbf{2 0 1 4}$ & $\mathbf{2 0 1 5}$ & $\mathbf{2 0 1 6}$ & $\mathbf{2 0 1 7}$ & $\mathbf{2 0 1 8}$ & $\mathbf{2 0 1 9}$ & $\mathbf{2 0 2 0}$ \\
\hline InMPP & 0,40 & 0,40 & 0,45 & 0,56 & 0,60 & 0,42 & 0,3 & 0,71 & 0,74 & 0,85 & 0,92 \\
\hline AMKR & 0,31 & 0,29 & 0,29 & 0,28 & 0,26 & 0,24 & 0,20 & 0,39 & 0,27 & 0,25 & 0,25 \\
\hline AMKR № 2-bis & 0,18 & 0,22 & 0,22 & 0,22 & 0,22 & 0,19 & 0,17 & 0,23 & 0,20 & 0,17 & 0,16 \\
\hline AMKR №3 & 0,39 & 0,33 & 0,33 & 0,32 & 0,28 & 0,28 & 0,22 & 0,49 & 0,31 & 0,31 & 0,31 \\
\hline SouthMPP & 0,37 & 0,30 & 0,26 & 0,22 & 0,22 & 0,19 & 0,19 & 0,16 & 0,16 & 0,13 & 0,13 \\
\hline CenMPP & 1,51 & 1,63 & 1,63 & 1,49 & 1,65 & 1,38 & 1,64 & 1,65 & 1,85 & 1,85 & 1,85 \\
\hline CenMPP №1 & 1,58 & 1,43 & 1,56 & 1,32 & 1,40 & 1,20 & 1,35 & 1,40 & 1,65 & 1,65 & 1,65 \\
\hline CenMPP №3 & 1,07 & 1,43 & 1,35 & 1,29 & 1,34 & 1,08 & 1,50 & 1,40 & 1,6 & 1,6 & 1,6 \\
\hline CenMPP №4 & 3,33 & 3,51 & 3,28 & 3,16 & 388 & 3,09 & 3,1 & 3,2 & 3,2 & 3,2 & 3,2 \\
\hline NorthMPP & 1,07 & 1,01 & 1,03 & 1,01 & 0.9 & 0.8 & 0.85 & 0.91 & 0,94 & 0,95 & 1.01 \\
\hline Gannivskyi & 1,68 & 1,50 & 1,57 & 1,55 & 1,4 & 1,38 & 1,3 & 1,4 & 1,47 & 1,5 & 1,56 \\
\hline Pershotravnevyi & 0,78 & 0,77 & 0,77 & 0,76 & 0,67 & 0,54 & 0,64 & 0,68 & 0,7 & 0,7 & 0,76 \\
\hline
\end{tabular}

For the designed open pit and basic operating open pits, we build a schedule of changes in the current overburden ratio according to the stages of reduction of mining works of conventional basic and conditional designed open pits (Fig. 3). Also we reconstruct on the graph the line of the calculated economic overburden ratio (line 1).

Based on the accepted mining and geological conditions of development of conditional deposits, the current overburden ratio in the further operation of the conditional base open pit №1 will decrease. In the further operation of the conditional base open pit №2, the current overburden ratio will increase until the design boundaries of the open pit on the surface are reached, and then gradually decrease. This change in the current overburden ratio is shown in Fig. 3 lines 2 and 3.

In these cases, the current overburden ratio of conditional base open pits №1 and №2 will be the cutoff ratio for the conditional (designed) open pit. If we calculate economic overburden ratio for the newly designed open pit without taking into account the timevarying current overburden ratio of the base open pits №1 and №2, as accepted for the present research, it will be constant, line 1 in Figure 3. Intersection of these lines (lines 1, 2, 3 in Fig. 3) with a line of current overburden ratio of the conditional open pit (designed) (line 4 in Fig. 3) gives the decision of definition of final depth of the given open pit mining.

As we can see from the presented graph (Fig. 3) for the conditional open pit (designed), there are three values of the final depth of its development:
- $\mathrm{H}_{1 \text { d.o.p }}$ - the final depth of the open pit, which is determined by a constant economic overburden ratio and is $560 \mathrm{~m}$;

$-\mathrm{H}_{2 \text { d.o.p. }}-$ the final depth of the open pit, which is determined by the current overburden of the conditional base open pit №1 and is $485 \mathrm{~m}$;

$-\mathrm{H}_{3 \text { d.o.p }}$ - the final depth of the open pit, which is determined by the current overburden ratio of the conditional base open pit №2 and is $800 \mathrm{~m}$.

The graphical solution for determining the final depth of the conditional open pit (designed) is presented in Fig. 4.

From Fig. 3 and 4 we can see that the deviation of the final mining depth of the designed conditional open pit, which is determined on the basis of comparing its current overburden ratio with the current overburden ratio of conventional basic open pit-competitors, from the final mining depth determined by constant overburden ratio from 14 to $45 \%$.

It follows from the above that to determine the boundaries of the designed open pit, the designed economic overburden ratio must be determined taking into account the possible change in the volume of overburden extraction and ore mining at basic enterprisescompetitors, that means to take into account changes in their current overburden ratio.

To confirm this, the design data of the open pits of Kryvbas were analyzed, which are presented in Table 2. The clarity of the dynamics of the current overburden ratio reflects the presented graph in Figure 5. 


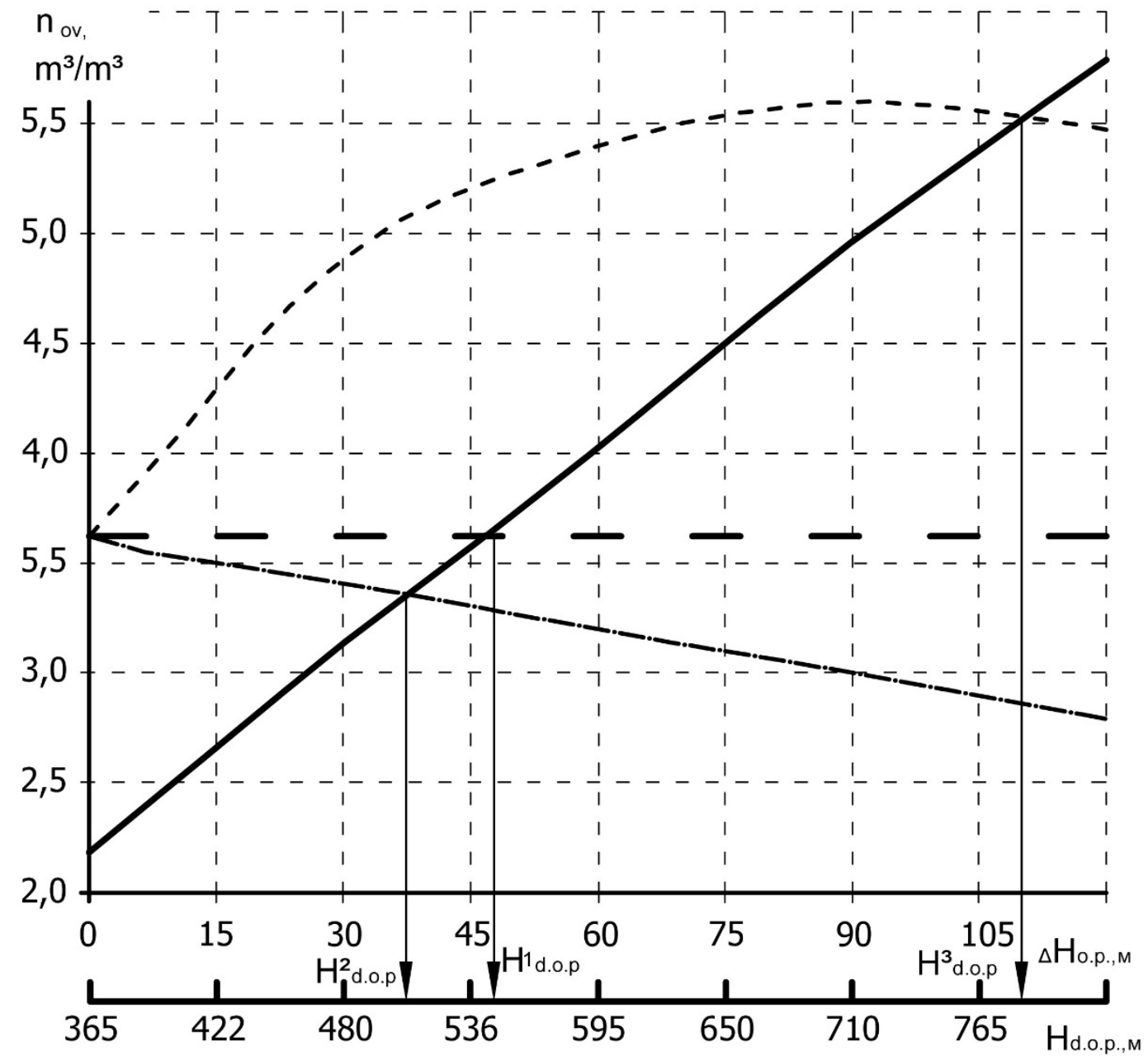

Fig. 3. Determination of the final depth mining of conditional open pit (designed): 1 - constant economic overburden ratio; $2-$ current overburden ratio according to the conditional base open pit № 1;3-current overburden ratio according to the conditional base open pit № 2; 4 - current overburden ratio according to the conditional open pit (designed).

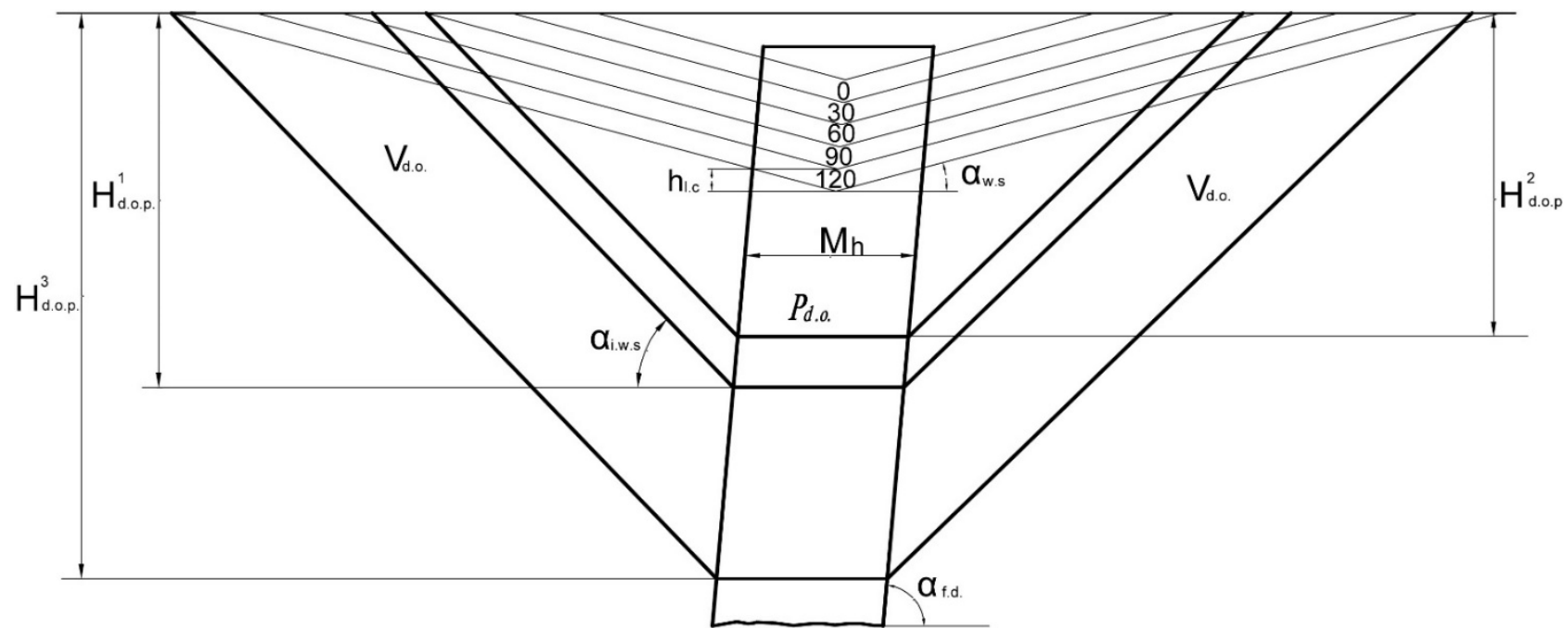

Fig. 4. Cross section of the deposit, that will be developed by the designed conditional open pit: $V_{\text {d.o. }}-$ overburden in the design contours of the open pit; $\mathrm{P}_{\text {d.o. }}-$ ore in the design contours of the open pit; $\mathrm{H}_{1 \text { d.o.p. }}$ - the final depth of the open pit mining, which is determined by a constant economic overburden ratio; $\mathrm{H}_{2 \text { d.o.p. }}$ - the final depth of the open pit, which is determined by the current overburden ratio of the conditional basic open pit-competitor №1; $\mathrm{H}_{3 \text { d.o.p. }}$ - the final depth of the open pit, which is determined by the current overburden ratio of the conditional basic open pit-competitor №2. 


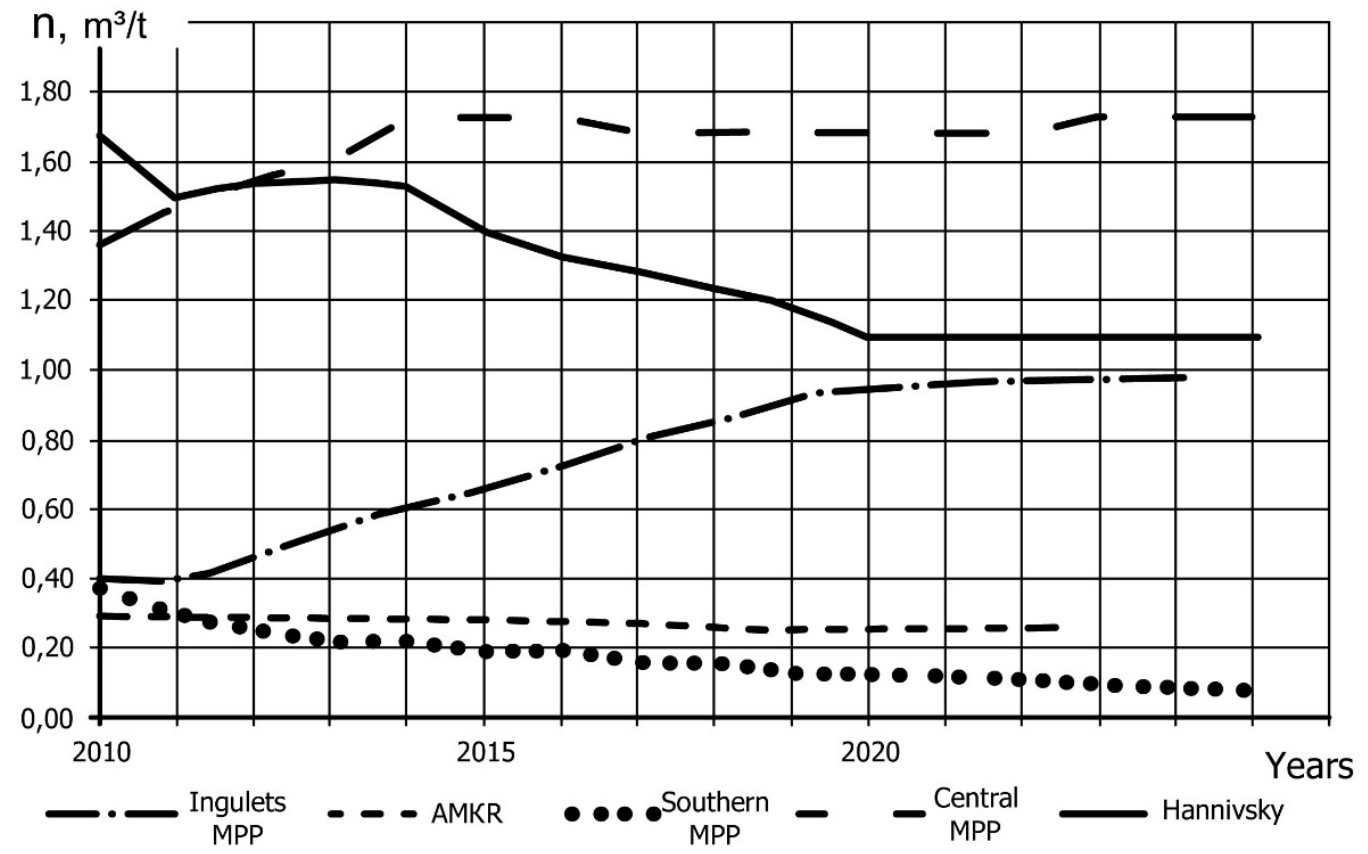

Fig. 5. Dynamics of the current overburden ratio on the open pits of Kryvbas on years of exploitation.

As we can see from the table, the current overburden ratios at the basic enterprises are changing over time. In addition, the indexes of every enterprise are open to different trends: they can grow, decrease or be relatively constant. It depends on whether the open pits have reached their contours on the surface, and whether the reconstruction or reactivation of the sides of open pits was carried on.

\section{Conclusions}

A new method for determining the final contours of mining the open pit has been developed, which differs from the known ones by taking into account the change in the economic overburden ratio in time, as well as determining the impact of technological indicators of open pits-competitors on the final depth of the designed open pit. It is proved that the deviation of the final depth of working of the designed conditional open pit, which is determined on the basis of comparing its current overburden ratio with the current overburden ratio of conventional basic open pits-competitors, from the final

\section{References}

1. Opredelenie perspektivnyh granic i proizvoditelnosti karera Inguleckogo gorno-obogatitelnogo kombinata, Otchet o NIR. (Gosudarstvennoe predpriyatie «Nauchno issledovatelskij gornorudnyj institute», Krivoy Rog, 2007).

2. Opredelenie perspektivnyh granic Annovskogo karera OAO «SevGOK», Otchet o NIR. (Gosudarstvennoe predpriyatie «Nauchno issledovatelskij gornorudnyj institute», Krivoy Rog, 2010)

3. M.I. Goberman, Inzhenernyj rabotnik 4, 24-28 (1927)
4. A.I. Arsentev, Konechnyie granitsyi karerov (Publishing Sankt-Peterburgskiy Gornyiy institute, Sankt-Peterburg, 1995), pp. 29-41

5. V.V. Rzhevskij, Proektirovanie konturov kar'erov (Metallurgizdat, Moscow, 1956), pp. 51-63.

6. B.P. Yumatov, Izvestiya vysshikh uchebnykh zavedeniy. Gornyy zhurnal 2, 45-53 (1962)

7. V.S. Hohryakov, Proektirovanie karerov (Nedra, Moscow, 1980), pp. 100-111

8. Ye. Malanchuk, V.Korniienko, L. Malanchuk, V. Zaiets. E3S Web of Conferences 201, 01036 (2020). doi:10.1051/e3sconf/202020101036

9. V. Korniyenko, V. Nadutyi, Y. Malanchuk, M. Yeluzakh. Mining of Mineral Deposits 14(4) (2020). doi:10.33271/mining14.04.090

10. Z. Malanchuk, V. Moshynskyi, P. Martyniuk, S. Stets, D. Galiyev. E3S Web of Conferences 211, 01011 (2020). doi:10.1051/e3sconf/202020101011

11. Z. Malanchuk, V. Moshynskyi, Y. Malanchuk, V. Korniienko, M. Koziar. Key Engineering Materials 844

(2020). doi:10.4028/www.scientist.net/KEM.844.77

12. V. Moshynskyi, Z. Malanchuk, V. Tsymbaliuk, L. Malanchuk, R. Zhomyruk, O. Vasylchuk. Mining of Mineral Deposits 14(2) (2020). doi:10.33271/mining14.02.095

13. Z. Malanchuk, V. Korniyenko, Ye. Malanchuk, A. Khrystyuk, M. Kozyar. E3S Web of Conferences 166, 02008

(2020). doi:10.1051/e3sconf/202016602008

14. A.I. Arsent'ev, Trudy KGRI 10, 97-115 (1961)

15. V.G. Bliznyukov, Opredelenie glavnyh parametrov karera s uchetom kachestva rudy (Nedra, Moscow, 1978), pp. 105-118 
16. V.G. Bliznyukov, I.V. Baranov. Visnik Kryvorizkoho tekhnichnoho universytetu 18, 7-11 (2007)

17. V. Kalinichenko, O. Dolgikh, L. Dolgikh, S. Pysmennyi. Mining of Mineral Deposits 14(4), 3139 (2020). doi:10.33271/mining14.04.031

18. O. Dolgikh, L. Dolgikh, I. Kuchnerov. E3S Web of Conferences 201, $01029 \quad$ (2020). doi:10.1051/e3sconf/202020101029

19. A. Selyukov, R. Rybár, Calculation of Boundary Stripping Ratio Errors at the Stage of Quarries Designing. E3S Web of Conferences 105, 01043 (2019). doi:10.1051/e3sconf/201910501043.

20. V. Kalyuzhin, F. Karavaytsyev, V. Shchukina, Determination of the limits of municipal formations in the inhomogeneous geoinformation space. E3S Web of Conferences 110, 02117 (2019). doi:10.1051/e3sconf/201911002117.

21. S. Moldabayev, B. Rysbaiuly, Zh. Sultanbekova, N. Sarybayev, Methodological approach to creation of the 3D model of an oval-shaped open pit mine. E3S Web of Conferences 123, 01049 (2019). doi:10.1051/e3sconf/201912301049.

22. V.G. Bliznyukov, I.V. Baranov, A.V. Savickij. Visnik Krivorizkogo nacionalnogo universitetu 31, 3-6 (2012)

23. Opredelenie perspektivnyh granic i proizvoditelnosti Pervomajskogo karera PAO «SevGOK», Otchet o NIR. (Akademiya gornyh nauk Ukrainy, Krivoy Rog, 2014).

24. Opredelenie perspektivnyh granic karera, obespechivayushih konkurentosposobnost zhelezorudnoj produkcii Poltavskogo GOKa, Otchet o NIR. (Gosudarstvennoe vysshee uchebnoe zavedenie «Krivorozhskij nacionalnyj universitet», Krivoy Rog, 2014).

25. V.G. Bliznyukov, S.A. Lucenko. Scientific bulletin of National Mining University 1(157), 44-49 (2017)

26. S.A. Lutsenko, V.G. Bliznyukov, Quality - Access to Success 18 (S1), 226-230 (2017)

27. Normy tekhnologicheskogo proektirovaniya gornodobyvayushchih predpriyatij s otkrytym sposobom razrabotki mestorozhdenij poleznyh iskopaemyh (Ministerstvo promyshlennoj politiki Ukrainy, Kiev, 2007), pp. 45-58

28. V. Mikhalchenko, The Concept of Resource Use Efficiency as a Theoretical Basis for Promising Coal Mining Technologies. E3S Web of Conferences 210, 4007. (2017). doi:10.1051/e3sconf/20172104007 